\title{
HUBUNGAN STATUS GIZI DAN BERAT LAHIR PADA ANAK USIA 2-3 TAHUN
}

\author{
${ }^{1}$ Eka Patandianan \\ ${ }^{2}$ Adrian Umboh \\ ${ }^{3}$ Sarah Warouw \\ ${ }^{1}$ Kandidat Skripsi Fakultas Kedokteran Universitas Sam Ratulangi Manado \\ ${ }^{2}$ Bagian Ilmu Kesehatan Anak Universitas Sam Ratulangi Manado \\ E-mail: ekaapriani.patandianan@yahoo.com
}

\begin{abstract}
Based on Riskesdas 2013, national prevalence of severely underweight 5,7\%, underweight 13,9\%, normal 75,9\% and overweight 4,5\%. Many factors affect the nutritional status of children under 5 years: socio-economic, maternal education, place of residence, birth status, infection, genetic, immunization, the status of breastfeeding, complementary feeding, health care, intervals of pregnancy and birth weight. Small for gestational age (SGA) refers to infants born weighing less than the weight of pregnancy it is supposed to. Catch up growth leads low birth weight baby to reach or to exceed a normal weight later. Catch up growth spontaneously occurred in 2 years old children and without spontaneous catch up growth at 3 years, it is not possible to experience it later without therapeutic intervention. The purpose of this study is to measure the weight and height of children aged between 2-3 years old with a history of SGA, determine nutritional status and determine the relationship between nutritional status and birth weight. This research took place at Prof Dr RD Kandou Hospital Manado and samples' house, from October to December 2014. This study was an observational analytic study with cross-sectional approach and used consecutive sampling method. There were 39 children aged between 2-3 years old with a history of SGA as samples, who were born in Prof Dr RD Kandou Hospital from December 2011 to December 2012. Nutritional status by weight for age 5,1\% severely underweight, $15,4 \%$ underweight, $79,5 \%$ normal; by height for age $25,6 \%$ severely stunted, $28,2 \%$ stunted and $46,2 \%$ normal; by weight for height $5,1 \%$ wasted, $89,8 \%$ normal and 5,1\% overweight; by BMI for age 5,1\% stunted, $84,6 \%$ normal and 10,3\% overweight. There is no relationship between nutritional status and birth weight in children aged between 2-3 years old with a history of SGA ( $p>0.05$ ).
\end{abstract}

Keywords: nutritional status, birth weight, SGA

Abstrak: Berdasarkan Riskesdas 2013, prevalensi nasional gizi buruk 5,7\%, gizi kurang 13,9\%, gizi baik 75,9\% dan gizi lebih 4,5\%. Banyak faktor yang yang mempengaruhi status gizi anak dibawah 5 tahun: sosial-ekonomi, pendidikan ibu, tempat tinggal, status kelahiran, infeksi, genetik, imunisasi, status menyusui, makanan pendamping, perawatan kesehatan, interval kehamilan dan berat lahir. Kecil masa kehamilan (KMK) mengacu pada bayi lahir dengan berat kurang dari berat seharusnya untuk masa kehamilan itu. Tumbuh kejar menyebabkan bayi dengan berat badan lahir rendah mencapai atau melebihi berat badan normal di kemudian hari. Tumbuh kejar spontan terjadi pada usia 2 tahun dan anak tanpa tumbuh kejar spontan pada usia 3 tahun tidak mungkin untuk mengalami hal itu kemudian tanpa intervensi terapeutik. Tujuan penelitian ini adalah untuk mengukur berat badan dan tinggi badan anak 2-3 tahun dengan riwayat KMK, menentukan status gizinya dan mengetahui hubungan antara status gizi terhadap berat lahir. Lokasi penelitian di RSUP Prof Dr RD Kandou Manado dan rumah sampel penelitian, dari Oktober-Desember 2014. Penelitian ini merupakan analitik observasional dengan pendekatan potong lintang dan menggunakan metode consecutive sampling. Didapatkan sampel sebanyak 39 anak usia 2-3 tahun dengan 
riwayat kecil masa kehamilan yang lahir di RSUP Prof Dr RD Kandou periode Desember 2011 - Desember 2012. Status gizi menurut BB/U gizi buruk 5,1\%, gizi kurang 15,4\%, gizi baik 79,5\%; menurut TB/U sangat pendek $25,6 \%$, pendek $28,2 \%$ dan normal $46,2 \%$; menurut BB/TB kurus 5,1\%, normal 89,8\% dan berat badan lebih 5,1\%; menurut IMT/U kurus 5,1\%, normal $84,6 \%$ dan berat badan lebih $10,3 \%$. Tidak ada hubungan antara status gizi dan berat lahir pada anak usia 2-3 tahun dengan riwayat KMK ( $>>0,05)$.

Kata kunci: status gizi, berat lahir, KMK

Berdasarkan Riskesdas 2013, prevalensi nasional gizi buruk 5,7\%, gizi kurang $13,9 \%$, gizi baik $75,9 \%$ dan gizi lebih 4,5\%. Untuk Provinsi Sulawesi Utara gizi buruk 3,7\%, gizi kurang $12,8 \%$, gizi baik $79 \%$ dan gizi lebih 4,5\%. ${ }^{1}$ Banyak faktor yang yang mempengaruhi status gizi anak dibawah 5 tahun: sosial-ekonomi, pendidikan ibu, tempat tinggal, status kelahiran, infeksi, genetik, imunisasi, status menyusui, makanan pendamping, perawatan kesehatan interval kehamilan, dan berat lahir. ${ }^{2}$ Istilah kecil masa kehamilan (KMK) mengacu pada berat badan lahir rendah sehubungan dengan usia kehamilan. Hal ini berarti bayi lahir dengan berat badan kurang dari berat badan seharusnya untuk masa kehamilan itu. Bayi kecil masa kehamilan adalah salah satu subjek populasi dengan gizi awal yang buruk dan akibatnya ditandai pertumbuhan postnatal awal yang bervariasi. ${ }^{3}$ Tumbuh kejar mengacu kecepatan pertumbuhan menurut usia di atas rata-rata, yang terjadi setelah adanya hambatan pertumbuhan. Tumbuh kejar terjadi spontan, tergantung usia anak dan menyebabkan bayi dengan berat badan lahir rendah mencapai atau melebihi berat badan normal di kemudian hari. ${ }^{5,6}$ Tumbuh kejar spontan terjadi pada usia 2 tahun dan anak tanpa tumbuh kejar spontan pada usia 3 tahun tidak mungkin untuk mengalami hal itu kemudian tanpa intervensi terapeutik. ${ }^{6}$

Berbagai studi mengemukakan bahwa tumbuh kejar berpotensi menguntungkan dalam jangka pendek, namun dapat merugikan kelangsungan hidup jangka panjang. $^{3,5}$ Berat badan yang cepat bertambah atau tumbuh kejar, dikaitkan dengan risiko yang lebih rendah untuk masuk rumah sakit dan kematian yang lebih rendah. Berat badan yang naik cepat dapat bermanfaat bagi anak, yaitu dengan peningkatan status gizinya, daya tahan terhadap infeksi dan kelangsungan hidup. ${ }^{6}$ Meskipun begitu mungkin ada biaya yang harus dibayar kemudian, dalam bentuk obesitas, toleransi glukosa terganggu pada orang dewasa muda, dan peningkatan mortalitas akibat penyakit jantung koroner. ${ }^{3}$ Banyak peneliti telah menemukan bahwa individu dengan tumbuh kejar memiliki keseimbangan somatik yang buruk, seperti ekspresi protein enzim antioksidan yang lebih buruk, ketidakpekaan insulin, telomere memendek, dll. Individu yang mengalami tumbuh kejar akan memiliki kualitas kesehatan yang lebih jelek, masa hidup lebih pendek dan menua lebih cepat dari seorang individu tidak mengalami pertumbuhan tumbuh kejar. ${ }^{5}$

Tujuan penelitian ini adalah untuk mengukur berat badan dan tinggi badan anak 2-3 tahun dengan riwayat KMK, menentukan status gizinya dan mengetahui hubungan antara status gizi terhadap berat lahir.

\section{METODE PENELITIAN}

Penelitian ini merupakan penelitian analitik observasional dengan pendekatan potong lintang (cross sectional). Penelitian dilakukan di RSUP Prof Dr RD Kandou Manado dan rumah sampel penelitian, dari Oktober hingga Desember 2014. Populasi dari penelitian ini adalah anak berusia 2-3 tahun dengan riwayat kecil masa kehamilan yang lahir di RSUP Prof Dr RD Kandou Manado periode Desember 2011 Desember 2012. Populasi dipilih untuk menjadi subjek penelitian berdasarkan kriteria inklusi dan ekslusi yang sudah ditetapkan. Kriteria inklusi meliputi : anak 
usia 2-3 tahun yang lahir di RSUP Prof Dr RD Kandou, riwayat kecil masa kehamilan, berdomisili di kota Manado dan bersedia mengikuti penelitian. Kriteria eksklusi meliputi : menderita kelainan kongenital dan sedang sakit. Dalam penentuan sampel peneliti menggunakan rumus sebagai berikut: ${ }^{7}$

$$
\mathrm{n}=\left[\frac{(z \alpha+z \beta)}{0,5 \ln [(1+r) /(1-r)]}\right]^{2}+3
$$

Keterangan :

$\mathrm{n}=$ besar sampel

$\mathrm{z} \alpha=$ derivate baku alpha $5 \%$, maka

$\mathrm{z} \alpha=1,96$

$\mathrm{z} \beta=$ derivate baku beta $20 \%$, maka

$\mathrm{z} \beta=0,842$

$\mathrm{r}=$ koefisien korelasi $=0,45$

ln = logaritma natural

Diperoleh $n=39$

Pengambilan sampel menggunakan metode non-probability sampling, yaitu dengan consecutive sampling. Variabel bebas adalah berat lahir dan variabel terikat adalah status gizi.

Definisi operasional dalam penelitian ini yaitu status gizi untuk anak kurang dari 5 tahun dinilai berdasarkan grafik pertumbuhan WHO, dalam hal ini z-scores. Ada 4 grafik $z$-scores yang dapat digunakan, yaitu BB/U, TB/U, BB/TB dan
IMT/U. Status gizi berdasarkan BB/U dibagi menjadi gizi buruk (dibawah -3), gizi kurang (dibawah -2), gizi baik (dibawah -1 dan median) dan gizi lebih (diatas 1). Status gizi berdasarkan TB/U dibagi menjadi perawakan sangat pendek (dibawah -3), perawakan pendek (dibawah -2), normal (dibawah -1 hingga diatas 2) dan perawakan tinggi (diatas 2). Status gizi berdasarkan $\mathrm{BB} / \mathrm{TB}$ dibagi menjadi sangat kurus (dibawah -3), kurus (dibawah -2), normal (dibawah -1 hingga diatas 1) dan obesitas (diatas 3). Status gizi berdasarkan IMT/U dibagi menjadi sangat kurus (dibawah -3), kurus (dibawah -2), normal (dibawah -1 hingga diatas 1) dan obesitas (diatas 3). ${ }^{8}$ Kecil masa kehamilan mengacu pada berat badan lahir rendah sehubungan dengan usia kehamilan. Hal ini berarti bayi lahir dengan berat badan kurang dari berat badan seharusnya untuk masa kehamilan itu. $^{3}$ Data diolah menggunakan SPSS (Statistical Program for Social Science) dalam bentuk distribusi frekuensi dan uji hipotesis korelasi dengan Spearman. ${ }^{9}$

\section{HASIL PENELITIAN}

Berdasarkan penelitian yang dilakukan pada anak riwayat KMK, diperoleh datadata yang dapat dilihat pada tabel-tabel di bawah

ini.

Tabel 1. Deskripsi statistik berat lahir

\begin{tabular}{ccccc}
\hline $\mathrm{N}$ & Minimum & Maksimum & Rerata & Simpang baku \\
\hline 39 & 1900 & 2450 & 2239,74 & 155,250 \\
\hline
\end{tabular}

Tabel 2. Distribusi berat badan lahir

\begin{tabular}{ccc}
\hline Jenis Kelamin & Berat lahir rendah (1500-2499 gram) & Persentase \\
\hline Laki-laki & 20 & $51,3 \%$ \\
Perempuan & 19 & $48,7 \%$ \\
\hline Total & 39 & $100 \%$ \\
\hline
\end{tabular}

Tabel 3. Distribusi status gizi anak berdasarkan berat badan/umur

\begin{tabular}{ccccccc}
\hline $\begin{array}{c}\text { Jenis } \\
\text { Kelamin }\end{array}$ & $\begin{array}{c}\text { Gizi } \\
\text { buruk }\end{array}$ & Persentase & $\begin{array}{c}\text { Gizi } \\
\text { kurang }\end{array}$ & Persentase & Gizi baik & Persentase \\
\hline Laki-laki & 2 & $5,1 \%$ & 1 & $2,6 \%$ & 15 & $38,5 \%$ \\
Perempuan & 0 & $0 \%$ & 5 & $12,8 \%$ & 16 & $41 \%$ \\
\hline Total & 2 & $5,1 \%$ & 6 & $15,4 \%$ & 31 & $79,5 \%$ \\
\hline
\end{tabular}


Tabel 4. Distribusi status gizi anak berdasarkan tinggi badan/umur

\begin{tabular}{ccccccc}
\hline Jenis Kelamin & Sangat pendek & Persentase & Pendek & Persentase & Normal & Persentase \\
\hline Laki-laki & 5 & $12,8 \%$ & 6 & $15,4 \%$ & 9 & $23,1 \%$ \\
Perempuan & 6 & $15,4 \%$ & 4 & $10,2 \%$ & 9 & $23,1 \%$ \\
\hline Total & 11 & $28,2 \%$ & 10 & $25,6 \%$ & 18 & $46,2 \%$ \\
\hline
\end{tabular}

Tabel 5. Distribusi status gizi anak berdasarkan berat badan/tinggi badan

\begin{tabular}{ccccccc}
\hline Jenis Kelamin & Kurus & Persentase & Normal & Persentase & BB lebih & Persentase \\
\hline Laki-laki & 2 & $5,1 \%$ & 16 & $41 \%$ & 1 & $2,55 \%$ \\
Perempuan & 0 & $0 \%$ & 19 & $48,8 \%$ & 1 & $2,55 \%$ \\
\hline Total & 2 & $5,1 \%$ & 35 & $89,8 \%$ & 2 & $5,1 \%$ \\
\hline
\end{tabular}

Tabel 6. Distribusi status gizi anak berdasarkan indeks massa tubuh/umur

\begin{tabular}{ccccccc}
\hline Jenis Kelamin & Kurus & Persentase & Normal & Persentase & BB lebih & Persentase \\
\hline Laki-laki & 2 & $5,1 \%$ & 16 & $41 \%$ & 2 & $5,15 \%$ \\
Perempuan & 0 & $0 \%$ & 17 & $43,6 \%$ & 2 & $5,15 \%$ \\
\hline Total & 2 & $5,1 \%$ & 33 & $84,6 \%$ & 4 & $10,3 \%$ \\
\hline
\end{tabular}

Tabel 7. Pengujian korelasi berat lahir dan status gizi

\begin{tabular}{lccccc}
\hline & & BB/U & TB/U & BB/TB & IMT/U \\
\hline Berat lahir & Koefisien korelasi $\left(r_{s}\right)$ & 0,216 & 0,013 & 0,265 & 0,222 \\
& Kemaknaan $(\mathrm{p})$ & 0,093 & 0,469 & 0,051 & 0,088 \\
\hline
\end{tabular}

\section{BAHASAN}

Penelitian dilakukan pada 39 orang anak usia 2-3 tahun dengan riwayat kecil masa kehamilan yang lahir di RSUP Prof Dr RD Kandou periode bulan Desember 2011 - Desember 2012. Didapatkan 20 orang yang berjenis kelamin laki-laki dan 19 orang yang berjenis kelamin perempuan. Dari jumlah tersebut diketahui status gizi menurut $\mathrm{BB} / \mathrm{U}$ gizi buruk $5,1 \%$, gizi kurang 15,4\%, gizi baik 79,5\% ; menurut $\mathrm{TB} / \mathrm{U}$ sangat pendek $25,6 \%$, pendek $28,2 \%$ dan normal 46,2\% ; menurut BB/TB kurus $5,1 \%$, normal $89,8 \%$ dan berat badan lebih 5,1\% ; menurut IMT/U kurus 5,1\%, normal $84,6 \%$ dan berat badan lebih 10,3\%.

Hasil ini sesuai dengan teori yang mengatakan bahwa percepatan dalam pertumbuhan terjadi pada $85 \%-90 \%$ bayi $\mathrm{KMK}^{3}$ Istilah tumbuh kejar dipakai untuk parameter pertumbuhan seperti berat, tinggi, komposisi tubuh, lingkar kepala, dan segmen tubuh (misalnya panjang kaki). Terdapat ketidakcocokan antara tumbuh kejar untuk tinggi dan lemak, yang terlihat pada bayi yang lahir kecil masa kehamilan, di mana ada peningkatan yang lebih besar pada adipositas daripada tinggi. Hal ini dikaitkan dengan risiko penyakit kardiovaskuler. $^{10}$

Dalam hal ini tidak didapatkan adanya hubungan yang bermakna dari berat lahir dengan status gizi berdasarkan $\mathrm{BB} / \mathrm{U}$, TB/U, BB/TB dan IMT/U ( $>0,05)$. Dari hasil uji analisis koefisien korelasi didapatkan adanya hubungan yang sangat lemah dari status gizi dan berat lahir. Selain itu menurut arah korelasinya, didapatkan korelasi status gizi dan berat lahir berdasarkan BB/U, TB/U, BB/TB dan IMT/U $\left(\left(r_{s}<0,4\right)\right.$ adalah korelasi positif. Korelasi positif artinya searah, semakin besar nilai berat lahir semakin besar pula nilai status gizi berdasarkan $\mathrm{BB} / \mathrm{U}, \mathrm{TB} / \mathrm{U}$, BB/TB dan IMT/U.

Hasil penelitian ini tidak sesuai dengan penelitian Gianini $\mathrm{dkk}^{11}$ yang menyatakan bahwa berat badan menurut usia menunjukkan korelasi langsung dengan 
berat badan lahir. Ia juga menyatakan bayi kecil untuk usia kehamilan memiliki kesempatan 12.19 kali lebih besar untuk kurang gizi pada jangka panjang. Namun penelitian yang dilakukan Lima $\mathrm{dkk}^{12}$, menyatakan berat lahir memiliki sedikit pengaruh pada status gizi anak. IMT dan tinggi ibu adalah kontributor terbesar untuk variasi pada $\mathrm{BB} / \mathrm{U}(12,3 \%)$ dan $\mathrm{TB} / \mathrm{U}$ $(13,2 \%)$, diikuti oleh kondisi sosial ekonomi keluarga. Status gizi ibu yang mencerminkan warisan genetik dan kondisi sosial ekonomi adalah penentu paling penting dari status gizi anak, bukan berat lahir.

Selain berat lahir, banyak faktor yang yang mempengaruhi status gizi anak dibawah 5 tahun. Faktor-faktor yang dapat meningkatkan status gizi anak antara lain : status sosial-ekonomi yang baik, pendidikan ibu sedang-tinggi, tempat tinggal di perkotaan, episode infeksi yang rendah (khususnya diare dan penyakit pernapasan), status menyusui yang baik (misalnya pemberian ASI eksklusif), status kelahiran (bayi bukan dengan kelahiran kembar), interval kelahiran $>2$ tahun, pemberian makanan pendamping sejak dini, imunisasi yang lengkap dan perawatan kesehatan yang cepat dan tepat waktu memiliki efek positif yang signifikan pada kesehatan anak. Selain itu status gizi dan kesehatan ibu juga genetika memainkan peran penting dalam pertumbuhan. ${ }^{2}$ Faktorfaktor ini tidak diteliti tetapi mempengaruhi hubungan antara status gizi dan berat lahir sehingga menjadi variabel perancu dalam penelitian ini.

Efek BBLR, tumbuh kejar dan massa tubuh dikemudian hari sebagai status kesehatan dan rentang hidup terjerat dalam data empiris. Para peneliti telah memperhatikan bahwa korelasi positif atau negatif antara satu variabel tersebut dan status kesehatan dapat dikaburkan oleh korelasi negatif atau positif antara salah satu dari variabel-variabel dan status kesehatan. $^{5}$ Namun, kelahiran prematur yang kurang dari 32 minggu kehamilan telah dikaitkan dengan risiko yang lebih besar tidak adanya tumbuh kejar. ${ }^{6}$

\section{SIMPULAN}

Tidak adanya hubungan antara status gizi dan berat lahir pada anak usia 2-3 tahun dengan riwayat kecil masa kehamilan ( $>0,05)$. Namun ada korelasi yang positif atau searah antara berat lahir dan status gizi. Artinya, semakin besar nilai berat lahir semakin besar pula nilai status gizi. Anak

usia 2-3 tahun dengan riwayat berat lahir rendah dan kecil masa kehamilan akan mengalami tumbuh kejar.

\section{SARAN}

Bagi peneliti yang ingin melanjutkan penelitian ini, disarankan melakukan penelitian dengan melihat usia kehamilan, apakah cukup atau kurang bulan dan meneliti faktor-faktor lain yang mempengaruhi status gizi anak.

Bagi tenaga kesehatan, perlu edukasi pada orang tua anak kecil masa kehamilan bahwa anak akan mengalami tumbuh kejar dan bahwa berat lahir bukan satu-satunya faktor yang mempengaruhi status gizi anak di kemudian hari. Orang tua juga perlu di edukasi faktor-faktor lain yang mempengaruhi status gizi.

\section{DAFTAR PUSTAKA}

1. Badan Penelitian dan Pengembangan Kesehatan Kementrian Kesehatan RI. Riset Kesehatan Dasar 2013 [Internet]. c2013 [updated 2013 Dec 1; cited 2014 Nov 8]. Available from: http://www.litbang.depkes.go.id/sites/d ownload/rkd2013/Laporan_Riskesdas2 013.PDF

2. Bhandari RT, Chhetri M. Nutritional Status of Under Five Year Children and Factor Associated in Kapilvastu District, Nepal. J Nutrition Health Food Sci [serial online]. 2013 [cited 2014 Dec 11]; 1(1):1-6. Available from: Symbiosis Online Publishing.

3. Han TY, Wang XL, Cui YP, Ye HM, Tong XM, Piao MH. No Weight Catch-Up Growth of SGA Infants Is Associated with Impaired Insulin Sensitivity during the Early Postnatal Period. Int J Pediatr [serial online]. 2010 [cited 2014 Nov 23]; 2010:1-5. 
Available from: Hindawi Publishing Corporation.

4. Pando R, Gat-Yablonski G, Phillip M. Nutrition and Catch-up Growth. J Pediatr Gastroent \& Nutr [serial online]. 2010 [cited 2014 Nov 29]; 51(3):129-30. Available from: Journal of Pediatric Gastroenterology and Nutrition.

5. Hou Chen, Bolt KM, Bergman A. Energetic Basis of Correlation Between Catch-Up Growth, Health Maintenance, and Aging. J Gerontol A Biol Sci Med Sci [serial online]. 2011 [cited 2015 Jan 3]; 66A(6):627-638. Available from: US National Library of Medicine, National Institute of Health.

6. Houk CP, Peter AL. Early diagnosis and treatment referral of children born small for gestational age without catchup growth are critical for optimal growth outcomes. Int $\mathrm{J}$ Pediatr Endocrinol [serial online]. 2012 [cited 2014 Oct 24]; 11. Available from: International Journal of Pediatrics Endocrinology

7. Sastroasmoro S, Ismael S. Perkiraan Besar Sampel. In: Madiyono B, Mz SM, Sastroasmoro S, Budiman I, Purwanto SH. Dasar-dasar Metodologi Penelitian Klinis. Edisi ke-4. Jakarta: Sagung Seto, 2011, p.372.
8. Ikatan Dokter Anak Indonesia. Asuhan Nutrisi Pediatrik [Internet]. C2011. [updated 2011 Jun; cited 2014 Dec 8]. Available from: http://idai.or.id/wpcontent/uploads/2013/02/RekomendasiIDAI_Asuhan-Nutrisi-Pediatrik.pdf

9. Sastroasmoro S, Ismael S. Pemilihan Uji Hipotesis. In: Tumbeleka AR, Riono P, Wirjodiarjo M, Pudjiastuti P, Kemas F. Dasar-dasar Metodologi Penelitian Klinis. Edisi ke-4. Jakarta: Sagung Seto, 2011, p.341-2.

10.De Wit CC, Sas TC, Wit JM, Cutfield WS. Patterns of Catch Up Growth. J Pediatr [serial online]. 2013 [cited 2014 Dec 13]; 162(2);415-20. Available from: The Journal of Pediatrics.

11.Gianini NM, Vieira AA, Moreira ME. Evaluation of the nutritional status at 40 weeks corrected gestational age in a cohort of very low birth weight infants. J Pediatr [serial online]. 2005 [cited 2014 Dec 8]; 20581(1):34-40. Available from: US National Library of Medicine, National Institute of Health.

12.Lima CM, Dantas EF, Amorim RJ, Lira PI. Does fetal growth restriction influence body composition at school age? J Pediatrics [serial online]. 2011 [cited 2015 Jan 10]; 87(1);29-35. Available from: Sceilo. 